\title{
EFFECT OF QUENCHING PARAMETERS ON THE MECHANICAL PROPERTIES OF THE 7A04 ALUMINIUM ALLOY
}

\author{
VPLIV PARAMETROV GAŠENJA NA MEHANSKE LASTNOSTI \\ ALUMINIJEVE ZLITINE 7A04
}

\author{
Dequan Shi, Kaijiao Kang, Guili Gao \\ Harbin University of Science \& Technology, Department of Materials Science \& Engineering 150040 Harbin, China \\ shidequan2008@163.com \\ Prejem rokopisa - received: 2015-08-30; sprejem za objavo - accepted for publication: 2016-01-05
}

doi:10.17222/mit.2015.267

\begin{abstract}
The effects of quenching parameters, including the solid-solution temperature, water temperature of quenching, transfer time before quenching and delay time after quenching on the mechanical properties of the 7A04 aluminium alloy were studied. The experimental results showed that the mechanical properties are relatively stable when the solid-solution temperature is at $460-490{ }^{\circ} \mathrm{C}$, but the over-burn will appears once the temperature exceeds $500{ }^{\circ} \mathrm{C}$. When the water temperature of quenching and the transfer time before quenching are above $40{ }^{\circ} \mathrm{C}$ and $20 \mathrm{~s}$, the strengths of the 7A04 alloy will drop remarkably. Before the delay time after quenching is $8 \mathrm{~h}$, the strengths will drop gradually while the elongation will rise continuously. In the range of $8-24 \mathrm{~h}$ there is an opposite change of mechanical properties compared to the previous $8 \mathrm{~h}$. Once it exceeds $24 \mathrm{~h}$, the mechanical properties will become stable.

Keywords: quenching parameters, 7A04 aluminium alloy, mechanical properties, delay time, transfer time
\end{abstract}

Preučevani so bili vplivi parametrov gašenja, vključno s temperaturo raztopnega žarjenja, časa prehoda pred gašenjem in časa zadrževanja po gašenju, na mehanske lastnosti aluminijeve zlitine 7A04. Rezultati eksperimentov so pokazali, da so mehanske lastnosti relativno stabilne, če je temperatura raztopnega žarjenja med $460{ }^{\circ} \mathrm{C}-490{ }^{\circ} \mathrm{C}$; zažgano pa je, ko temperatura preseže $500{ }^{\circ} \mathrm{C}$. Ko je temperatura vode za gašenje nad $40{ }^{\circ} \mathrm{C}$ in čas prehoda pred gašenjem nad $20 \mathrm{~s}$, se trdnosti zlitine $7 \mathrm{~A} 04$ občutno zmanjšajo. Pri času zadrževanja do $8 \mathrm{~h}$ po gašenju, se trdnost stalno zmanjšuje, medtem ko se raztezek povečuje. V času od $8-24 \mathrm{~h}$ je ravno obratna sprememba mehanskih lastnosti, v primerjavi s predhodnimi pri $8 \mathrm{~h}$. Ko čas preseže $24 \mathrm{~h}$, mehanske lastnosti postanejo stabilne.

Ključne besede: parametri gašenja, aluminijeva zlitina 7A04, mehanske lastnosti, čas zadrževanja, čas prehoda

\section{INTRODUCTION}

7A04 is a high-strength aluminium alloy of the $\mathrm{Al}-\mathrm{Zn}-\mathrm{Mg}-\mathrm{Cu}$ series. Due to the high strength and hardness, good corrosion resistance and wear resistance, it has become a key structural material in the aerospace field instead of the steels. ${ }^{1,2}$ Generally speaking, $\mathrm{Al}-\mathrm{Zn}-\mathrm{Mg}-\mathrm{Cu}$ series aluminium alloys are produced by the method of electromagnetic semi-continuous casting, ${ }^{3}$ and then their properties were improved by the solution and aging treatment. Therefore, the heat-treatment parameters will directly affect the mechanical properties of the 7A04 aluminium alloy. At present, many experimental researches on optimizing the solution and aging treatment parameters had also been widely reported. For example, from the aspects of improving both the mechanical properties and the efficiency of heat treatment, A. L. Ning et al. ${ }^{4}$ studied the influences of loading the specimen at high temperature, rapid short-time progressive solution and high-temperature short-time aging on the microstructure and mechanical properties of 7A04 aluminium alloy, respectively. J. J. Liu et al. ${ }^{5}$ investigated the influence of the solid-solution conditions on the microstructure and resistivity of $\mathrm{Al}-\mathrm{Zn}-\mathrm{Mg}-\mathrm{Cu}$ series alloy by in-situ resistivity measurement, optical microscopy, scanning electron microscopy, transmission electron microscopy. O. N. Senkov et al. ${ }^{6}$ studied the effect of Sc additions on precipitation strengthening in a direct chill-cast $\mathrm{Al}-\mathrm{Zn}-\mathrm{Mg}-\mathrm{Cu}$ alloy after natural and artificial aging. The microhardness, room-temperature mechanical properties, and phase composition of the alloys were determined after different steps of aging, and the strengthening mechanism was discussed. Y. Lin et al. ${ }^{7}$ studied the effect of non-isothermal cooling aging on the microstructure and mechanical properties of an $\mathrm{Al}-\mathrm{Zn}-\mathrm{Mg}-\mathrm{Cu}$ alloy, and the tensile strength, yield strength and conductivity were increased $2.9 \%, 8.1 \%$ and $8.3 \%$ compared to that of the $\mathrm{T} 6$ treatment, respectively. T. Marlaud et al. ${ }^{8}$ studied the influence of alloy composition and heat treatment on the precipitate composition. However, the effects of the quenching parameters on the microstructure and mechanical properties are rarely studied. Therefore, there is an urgent need to investigate how the quenching parameters affect the mechanical properties, which will further improve the mechanical properties and product quality of the 7A04 aluminium alloy.

In this study, the mechanical properties are measured using a CSS-44300 electronic universal testing machine, and the microstructures are observed by optical micro- 


\section{MATERIALI IN TEHNOLOGIJE/MATERIALS AND TECHNOLOGY (1967-2017) - 50 LET/50 YEARS}

\section{D.-Q. SHI et al.: EFFECT OF QUENCHING PARAMETERS ON THE MECHANICAL PROPERTIES OF THE 7A04 ...}

scopy. The effect of the solid-solution temperature, water temperature of quenching, transfer time before quenching and delay time after quenching on the mechanical properties of 7A04 aluminium alloy were studied, respectively, and the optimal quenching parameters were also obtained according to the experimental results.

\section{EXPERIMENTAL PART}

The experimental materials are hot-rolled 7A04 aluminium alloy plates with $12 \mathrm{~mm}$ thickness, and their chemical compositions are shown in Table $\mathbf{1 .}$

Table 1: Chemical composition of 7A04 aluminium alloy, in mass fractions $(w / \%)$

Tabela 1: Kemijska sestava aluminijeve zlitine 7A04, v masnih odstotkih $(w / \%)$

\begin{tabular}{|c|c|c|c|c|c|c|c|}
\hline $\mathrm{Zn}$ & $\mathrm{Mg}$ & $\mathrm{Cu}$ & $\mathrm{Cr}$ & $\mathrm{Fe}$ & $\mathrm{Si}$ & $\mathrm{Mn}$ & $\mathrm{Ti}$ \\
\hline 6.05 & 2.62 & 1.53 & 0.18 & 0.16 & 0.08 & 0.45 & 0.02 \\
\hline
\end{tabular}

Because the 7A04 aluminium alloy is not online quenched during industrial production, it is very important to choose optimal quenching parameters. In this study, through independently altering the solid-solution temperature, the water temperature of quenching, transfer time before quenching and delay time after quenching, the effects of the quenching parameters on the mechanical properties of 7A04 aluminium alloy were investigated, respectively. If the solid-solution temperature was too high, the over-burn phenomenon in the microstructure of 7A04 aluminium alloy might appear. Therefore, the microstructure was observed by the OLYMPUS-GX71 optical microscopy when the solidsolution temperature was studied.

The hot-rolled 7A04 aluminium alloy plates were homogenized at $460 \pm 5^{\circ} \mathrm{C} / 24 \mathrm{~h}$, and the standard samples were prepared by horizontally cutting on the plates according to the GB/T228-2010 of China. The samples were heated to different temperatures in the salt bath furnace and the time of holding at temperature was 60 min. Then the samples were quenched according to the experimental design, and artificial aging treatment of $130 \pm 5{ }^{\circ} \mathrm{C} / 24 \mathrm{~h}$ was carried out. In order to study the effects of the quenching parameters on the mechanical properties, the following experiments were designed.

1) When the water temperature of quenching, transfer time before quenching and delay time after quenching were kept at $30^{\circ} \mathrm{C}, 20 \mathrm{~s}$ and $2 \mathrm{~h}$, respectively, the solid-solution temperature was changed from $400{ }^{\circ} \mathrm{C}$ to $510{ }^{\circ} \mathrm{C}$ with the step of $10{ }^{\circ} \mathrm{C}$.

2) When the solid-solution temperature, transfer time before quenching and delay time after quenching were kept at $470{ }^{\circ} \mathrm{C}, 20 \mathrm{~s}$ and $2 \mathrm{~h}$, respectively, the water temperature of quenching was changed from 10 ${ }^{\circ} \mathrm{C}$ to $80{ }^{\circ} \mathrm{C}$ with a step of $10^{\circ} \mathrm{C}$.

3) When the solid-solution temperature, water temperature of quenching and delay time after quenching were kept at $470{ }^{\circ} \mathrm{C}, 30{ }^{\circ} \mathrm{C}$ and $1 \mathrm{~h}$, respectively, the transfer time before quenching was changed at $5 \mathrm{~s}$ and from $10 \mathrm{~s}$ to $60 \mathrm{~s}$ with a step of $10 \mathrm{~s}$.

4) When the solid-solution temperature, water temperature of quenching and transfer time before quenching were kept at $470{ }^{\circ} \mathrm{C}, 30^{\circ} \mathrm{C}$ and $20 \mathrm{~s}$, respectively, the delay time after quenching was set to be $1 \mathrm{~h}, 2 \mathrm{~h}, 4 \mathrm{~h}$, $8 \mathrm{~h}, 16 \mathrm{~h}, 24 \mathrm{~h}, 48 \mathrm{~h}$ and $72 \mathrm{~h}$.

\section{RESULTS AND DISCUSSION}

\subsection{Effect of solid-solution temperature on the mecha- nical properties and microstructure}

Figure 1 shows the change of the mechanical properties of the 7A04 alloy with solid-solution temperature. With the increase of the solid-solution temperature, the tensile strength and yield strength will first increase and then decrease, but the elongation will drop monotonically. Before the solid-solution temperature reaches up to $460{ }^{\circ} \mathrm{C}$, the tensile strength and yield strength will rapidly increase. Once the temperature excess $460{ }^{\circ} \mathrm{C}$, the increase rate will become very slow.

This can be explained as follows. In general, to improve the solid-solution temperature at a certain range is an effective means to improve the strength. When the temperature was increased, the rate of dissolving the second-phase particles will increase. As a result, it can promote the number of the strengthening precipitation phase, thus the tensile strength and yield strength will increase. However, the increase in the temperature will make the recrystallization grain grow up, which will result in the decrease of the strength. ${ }^{9,10}$ Therefore, when the temperature was reached to a certain value, the increase rate of the strength will become slow.

The mechanical properties were satisfied when the solid-solution temperature was kept at $460-490{ }^{\circ} \mathrm{C}$, which proves that there is a wide range of solid-solution temperatures for the 7A04 aluminium alloy. But when

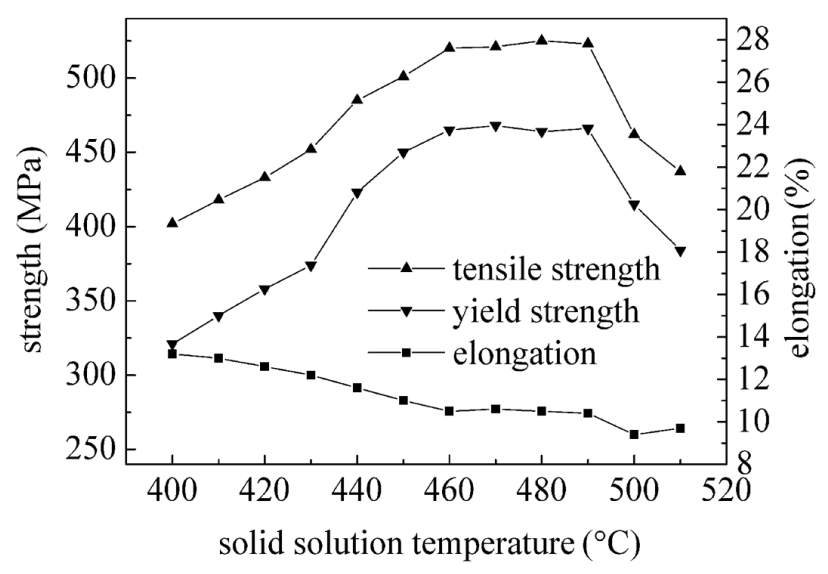

Figure 1: Mechanical properties changing with solution temperature Slika 1: Spreminjanje mehanskih lastnosti v odvisnosti od temperature raztopnega žarjenja 

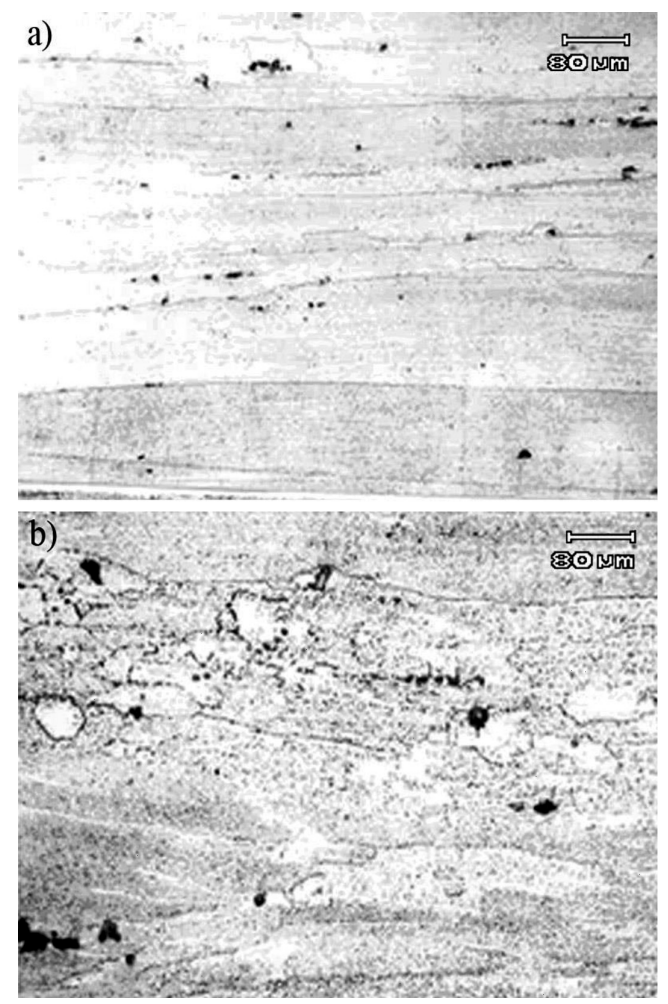

Figure 2: Microstructure at different solution temperatures: a) $470{ }^{\circ} \mathrm{C}$, b) $500{ }^{\circ} \mathrm{C}$

Slika 2: Mikrostruktura pri različnih temperaturah raztopnega žarjenja: a) $470{ }^{\circ} \mathrm{C}$, b) $500{ }^{\circ} \mathrm{C}$

the temperature is more than $500{ }^{\circ} \mathrm{C}$, the tensile strength and yield strength will drop suddenly.

Figure 2 showed the microstructures at $470{ }^{\circ} \mathrm{C}$ and $500{ }^{\circ} \mathrm{C}$, respectively. As shown in Figure 2a, the overburn was not found in the microstructure. The partially recrystallized grains appear and they are elongated along the deformation direction. Some of the residual phase and the insoluble phase are broken, and they symmetrically arrange along the deformation direction. However, it can be seen from Figure $\mathbf{2 b}$ that the obvious over-burn

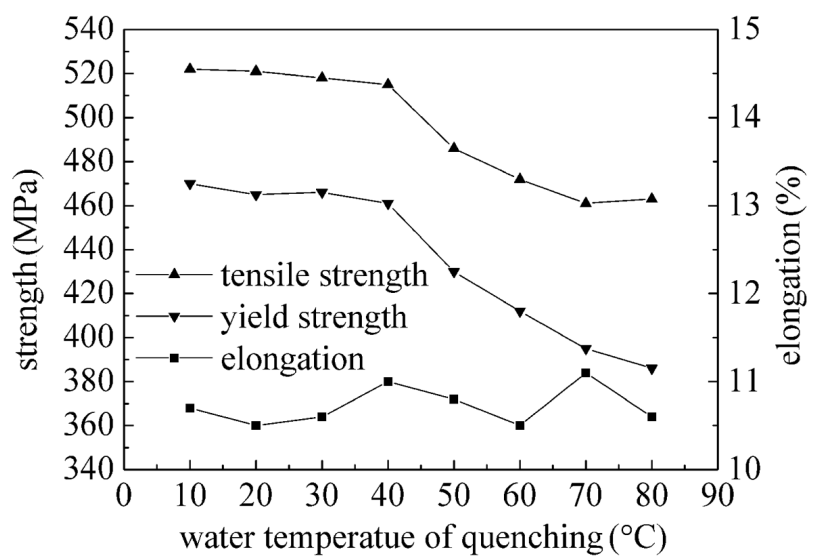

Figure 3: Mechanical properties changing with water temperature of quenching

Slika 3: Spreminjanje mehanskih lastnosti s temperaturo vode pri gašenju and the complex re-melting grain boundaries appear. According to the relevant literature ${ }^{11-13}$ the precipitated phases continuously distribute at the re-melting grain boundary. The evenly distributed fine precipitated phases inside the grains are the coherent GP zone and the small amount of transition phase. In addition, some of the large particles randomly distribute in the grain and/or the grain boundaries, and they are the main strengthening phase and the impurity phase.

\subsection{Effect of water temperature of quenching on me- chanical properties}

The effect of the water temperature of quenching on the mechanical properties of the 7A04 aluminium alloy was shown in Figure 3. When the water temperature of quenching is below $40{ }^{\circ} \mathrm{C}$, the tensile strength, yield strength and elongation are almost unchanged. However, when the water temperature is more than $40{ }^{\circ} \mathrm{C}$, the tensile strength and yield strength decrease remarkably, while the elongation is found to have little change. This indicates that the 7A04 alloy is sensitive to the cooling rate.

The effect of the water temperature on the mechanical properties can be attributed to the cooling rate. It is well known that the precipitation sequence of the $\mathrm{Al}-\mathrm{Zn}-\mathrm{Mg}-\mathrm{Cu}$ series alloy at the ageing treatment is super-saturation solid solution, GP zone, $\eta$ ' phase and $\eta$ phase. So, the size, density and distribution of GP zone are very important for the forming of the $\eta^{\prime}$ phase. When the water temperature is below $40{ }^{\circ} \mathrm{C}$, the cooling rate is large, and there is not enough time for the second phase to nucleate and precipitate at the grain boundary, which makes the concentration of solute atoms become higher. A lot of stable GP zones can form quickly. During ageing, many second phases can uniformly precipitate, and their sizes are not very different. So the strengthening effect is good, and the mechanical properties of 7A04 alloy are promoted. In contrast, when the water temperature increases and the cooling rate becomes small,

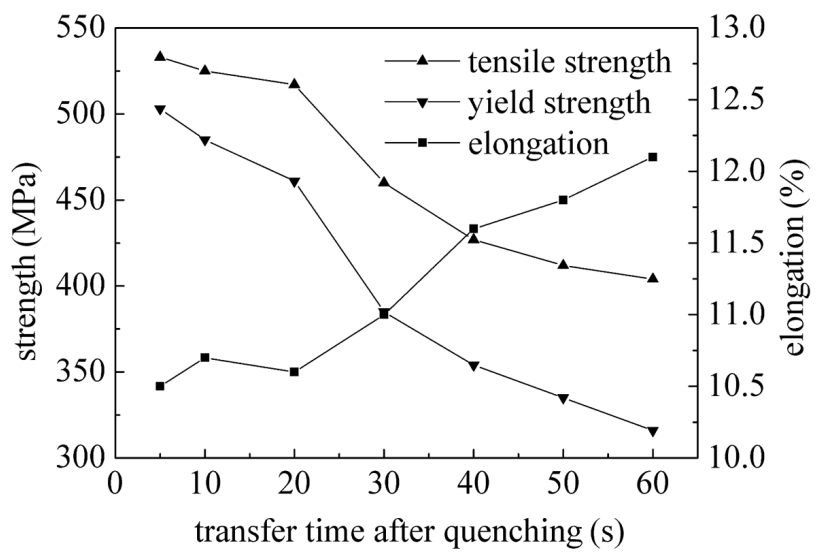

Figure 4: Mechanical properties changing with transfer time before quenching

Slika 4: Spreminjanje mehanskih lastnosti s časom prehoda pred gašenjem 
there is enough time for the second phase to nucleate and precipitate at the grain boundary, and the formation of second phases will result in a decrease of the salute atom concentration at the grain boundary. During ageing, these second phases can continue to grow by absorbing the solute atoms near the grain boundary. So the GP zones will become few and instable. Therefore, the strengthening effect will become weak, and thus the mechanical properties of the 7A04 alloy will decrease.

Therefore, the water temperature of quenching should be kept below $40{ }^{\circ} \mathrm{C}$. Actually, in order to avoid the quenching crack caused by the excessive stress, the cooling rate must be small. So, the water temperature must be high, which is contradictory to the requirement of a low water temperature due to improving the strength. Consequently, during practical production, the water temperature of quenching is as low as possible on the condition that the stress cracks do not occur.

\subsection{Effect of transfer time before quenching on the me- chanical properties}

The effect of the transfer time before quenching on the mechanical properties of the 7A04 aluminium alloy was shown in Figure 4. When the transfer time before quenching is less than $20 \mathrm{~s}$, a small effect can be found. But when the transfer time is more than $30 \mathrm{~s}$, the tensile strength and yield strength will drop while the elongation will rise. So the transfer time should be kept within $20 \mathrm{~s}$.

This can be explained as follows. Because of the additive $\mathrm{Mn}$ and $\mathrm{Cr}$, the 7A04 aluminium alloy is sensitive to the quenching. Before the alloy was put into the water, it was cooled in the air, and the cooling rate is very small. When the transfer time was extended, there was plenty of time for the second phase to nucleate on the grain boundary and grow to a certain extent. According to the Ostwald ripening mechanism ${ }^{14,15}$ the second phase can absorb the solute atoms near the grain boundary and continue to grow during aging. It will lead to

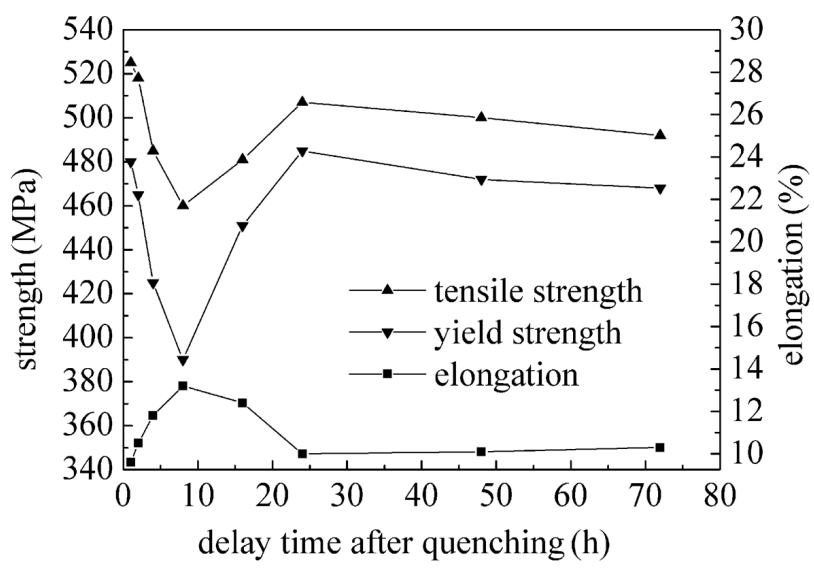

Figure 5: Mechanical properties changing with delay time after quenching

Slika 5: Spreminjanje mehanskih lastnosti s časom zadrževanja po gašenju the poor area of solute atoms near the grain boundary, and make it difficult of the precipitation of a new second phase on the grain boundary. So the distribution of the precipitated phase on the grain boundary is discontinuous and their size difference becomes too big. On the other hand, the supersaturated vacancy concentration after quenching differs in different areas. During the cooling process, the vacancy will diffuse to the grain boundary, and it will cause a decrease of the vacancy concentration near the grain boundary. However, the vacancy away from the grain boundary has no space to diffuse, and thus the concentration is relatively higher. As a result, a concentration gradient was formed. When the transfer time is longer, more vacancies disappeared in the grain boundary. During the aging treatment the GP zone cannot appear in the area that is lower than the critical vacancy concentration, and thus a precipitation free zone will form. ${ }^{16-18}$ So, if the transfer time was extended, the width of the precipitation free zone would become large, and the mechanical properties of the alloy would be deteriorated.

\subsection{Effect of delay time after quenching on the mecha- nical properties}

Figure 5 shows the effect of the delay time after quenching on the mechanical properties of the 7A04 aluminium alloy, which indicated the tensile strength and yield strength is on the decline as a whole with the delay time. Within $8 \mathrm{~h}$, the strengths drop gradually and the elongation rises continuously with the increase of the delay time. From $8 \mathrm{~h}$ to $24 \mathrm{~h}$ a rebound of the mechanical properties appears, and the strengths will rise and the elongation will drop. When the delay time is more than $24 \mathrm{~h}$, the mechanical properties of 7A04 alloy are stable.

In fact, this obvious delay time effect began once the quenching was done, and it is related to the dissolution of the GP zone. ${ }^{19}$ Along with the extension of the delay time, a large number of partial poly groups will form, and thus the concentration of solute elements in solid solutions is greatly reduced. During the artificial aging, the GP zones that are less than the critical size will resolve back to the solid solution, and it will reduce the number of the precipitation strengthening phases. So, the strength of the alloy will reduce. But if the delay time continues to be extended, those GP zones that are less than the critical size are likely to grow up to the stable crystal nucleus. Therefore, the delay time effect became weak, and the mechanical properties of the alloy began to recover. Considering the practical production, the delay time after quenching is confined into $2 \mathrm{~h}$. If there is not enough time, the artificial aging can be performed after the delay time of $24 \mathrm{~h}$, which also can give ideal comprehensive performances.

\section{CONCLUSIONS}

1. In the range of $460-490{ }^{\circ} \mathrm{C}$, the mechanical properties of the 7A04 alloy are relatively stable. When the 


\section{MATERIALI IN TEHNOLOGIJE/MATERIALS AND TECHNOLOGY (1967-2017) - 50 LET/50 YEARS}

\section{D.-Q. SHI et al.: EFFECT OF QUENCHING PARAMETERS ON THE MECHANICAL PROPERTIES OF THE 7A04 ...}

solid solution is higher than $500{ }^{\circ} \mathrm{C}$, over-burn may appear.

2. When the water temperature of quenching exceeds 40 ${ }^{\circ} \mathrm{C}$ or the transfer time before quenching is more than $20 \mathrm{~s}$, the tensile strength and yield strength will drop remarkably while the elongation will rise.

3. The tensile strength and yield strength will drop gradually while the elongation will rise continuously with the delay time after quenching before $8 \mathrm{~h}$. At the range of 8-24 $\mathrm{h}$ there is an opposite change of mechanical properties compared to the previous $8 \mathrm{~h}$. Once the delay time exceeds $24 \mathrm{~h}$, the mechanical properties become stable.

4. The optimal quenching parameters are as follows. The solid solution temperature is $460-490{ }^{\circ} \mathrm{C}$, and the water temperature of quenching and the transfer time before quenching are below $40{ }^{\circ} \mathrm{C}$ and $20 \mathrm{~s}$, respectively, and the delay time after quenching is below $2 \mathrm{~h}$ or above $24 \mathrm{~h}$.

\section{Acknowledgement}

This research was financially supported by Foundation of Heilongjiang Educational Committee (12541107) and Natural Science Foundation of Heilongjiang Province (F201213).

\section{REFERENCES}

${ }^{1}$ M. Nakai, T. Eto, New aspect of development of high strength aluminum alloys for aerospace applications, Mater. Sci. Eng., B, 285 (2000) 1-2, 62-68, doi:10.1016/S0921-5093(00)00667-5

${ }^{2}$ D. Vojtěch, J. Šerák, O. Ekrt, Improving the casting properties of high-strength aluminium alloys, Mater. Tehnol., 38 (2004) 1-2, 99-102

${ }^{3}$ Y. Zuo, J. Cui, Z. Zhao, H. Zhang, L. Li, Q. Zhu, Mechanism of grain refinement of an $\mathrm{Al}-\mathrm{Zn}-\mathrm{Mg}-\mathrm{Cu}$ alloy prepared by low frequency electromagnetic casting, J. Mater. Sci., 47 (2012) 14, 5501-5508, doi:10.1007/s10853-012-6441-Z

${ }^{4}$ A. L. Ning, Z. Y. Liu, Q. C. Zheng, S. M. Zeng, Effects of progressive solution treatment on microstructure and mechanical properties of 7A04 aluminum alloy, The Chinese Journal of Nonferrous Metals, 14 (2004) 7, 1211-1216, doi:10.3321/j.issn:1004-0609.2004.07.028

${ }^{5}$ J. J. Liu, H.Y. Li, D. W. Li, Y. Wu, Application of novel physical picture based on artificial neural networks to predict microstructure evolution of Al-Zn-Mg-Cu alloy during solid solution process, Trans. Nonferrous Met. Soc. China, 25 (2015) 3, 944-953, doi:10.1016/S1003-6326(15)63683-4

${ }^{6}$ O. N. Senkov, S. V. Senkova, M. R. Shagiev, Effect of Sc on aging kinetics in a direct chill cast $\mathrm{Al}-\mathrm{Zn}-\mathrm{Mg}-\mathrm{Cu}$ alloy, Metall. Mater.
Trans. A-Phys. Metall. Mater. Sci., 39 (2008) 5, 1034-1053, doi: 10.1007/s11661-008-9485-6

${ }^{7}$ Y. Liu, D. M. Jiang, B. Q. Li, W. S. Yang, J. Hu, Effect of cooling aging on microstructure and mechanical properties of an Al-Zn$\mathrm{Mg}-\mathrm{Cu}$ alloy, Mater. Des., 57 (2014) 5, 79-86, doi:10.1016/ j.matdes.2013.12.024

${ }^{8}$ T. Marlaud, A. Deschamps, F. Bley, W. Lefebvre, B. Baroux, Influence of alloy composition and heat treatment on precipitate composition in Al-Zn-Mg-Cu alloys. Acta Mater., 58 (2010) 1, 248-260, doi:10.1016/j.actamat.2009.09.003

${ }^{9}$ G. S. Wang, Z. H. Zhao, Y. H. Zhang, J. Z. Cui, Effects of solution treatment on microstructure and mechanical properties of Al-9.0Zn-2.8Mg-2.5Cu-0.12Zr-0.03Sc alloy. Trans. Nonferrous Met. Soc. China, 23 (2013) 9, 2537-2542, doi:10.1016/S10036326(13)62765-x

${ }^{10}$ O. N. Senkov, M. R. Shagiev, S. V. Senkova, D. B. Miracle, Precipitation of $\mathrm{Al}_{3}(\mathrm{Sc}, \mathrm{Zr})$ particles in an $\mathrm{Al}-\mathrm{Zn}-\mathrm{Mg}-\mathrm{Cu}-\mathrm{Sc}-\mathrm{Zr}$ alloy during conventional solution heat treatment and its effect on tensile properties, Acta Mater., 56 (2008) 15, 3723-3738, doi:10.1016/ j.actamat.2008.04.005

${ }^{11}$ M. Meng, Z. M. Zhang, J. M. Yu, X. K. Li, Effect of heat treatments on microstructure and properties of hot compression aluminum alloy 7A04, Key Eng. Mater., 480-481 (2011), 433-436, doi:10.4028/ www.scientific.net/KEM.480-481.433

${ }^{12}$ C. J. Yi, P. C. Zhai, L. Z. Dong, Q. H. Fu, Research on the strength improvement of 7A04 aluminum alloy, Adv. Mater. Res., 488-489 (2012), 19-21, doi:10.4028/www.scientific.net/AMR.488-489.19

${ }^{13}$ V. V. Antipov, O. G. Senatorova, E. A. Tkachenko, R. O. Vakhromov, High-strength Al-Zn-Mg-Cu alloys and light Al-Li alloys, Met. Sci. Heat Treat., 53 (2012) 9, 428-433, doi:10.1007/s11041-012-9410-x

${ }^{14}$ A. Baldan, Review progress in Ostwald ripening theories and their applications to nickel-base superalloys part I: Ostwald ripening theories, J. Mater. Sci., 37 (2002) 11, 2171-2202, doi:10.1023/ A: 1015388912729

${ }^{15}$ T. Philippe, P. W. Voorhees, Ostwald ripening in multicomponent alloys, Acta Mater., 61 (2013) 11, 4237-4244, doi:10.1016/j.actamat. 2013.03.049

${ }^{16}$ J. D. Bernardin, I. Mudawar, Validation of the quench factor technique in predicting hardness in heat treatable aluminum alloys, Int. J. Heat Mass Transf., 38 (1995) 5, 863-873, doi:10.1016/00179310(94)00204-9

${ }^{17}$ T. Ogura, S. Hirosawa, A. Cerezo, T. Sato, Atom probe tomography of nanoscale microstructures within precipitate free zones in Al-Zn-Mg(-Ag) alloy, Acta Mater., 58 (2010)17, 5714-5723, doi:10.1016/j.actamat.2010.06.046

${ }^{18}$ T. Ogura, S. Hirosawa, A. Hirose, T. Sato, Effects of microalloying tin and combined addition of silver and tin on the formation of precipitate free zones and mechanical properties in $\mathrm{Al}-\mathrm{Zn}-\mathrm{Mg}$ alloys, Mater. Trans., 52 (2011) 5, 900-905, doi:10.2464/jilm.61.316

${ }^{19}$ P. A. Rometsch, Y. Zhang, S. Knight, Heat treatment of 7xxx series aluminum alloys-some recent developments, Trans. Nonferrous Met. Soc. China, 24 (2014) 7, 2003-2017, doi:10.1016/S1003-6326(14) 63306-9 